\title{
EFEKTIVITAS PELATIHAN CUSTOMER SERVICE ORIENTATION UNTUK MENURUNKAN EMOTIONAL EXHAUSTION KARYAWAN PEMASARAN
}

\section{EFFECTIVENESS OF TRAINING CUSTOMER SERVICE ORIENTATION TO REDUCE EMOTIONAL EXHAUSTION IN MARKETING EMPLOYEES}

\author{
Muhammad Jufri' ${ }^{1}$, Alimatus Sahrah² \\ ${ }^{1}$ Universitas Negeri Makassar, ${ }^{2}$ Universitas Mercu Buana Yogyakarta \\ ${ }^{1}$ m.jufri@unm.ac.id, 2alin@mercubuana-yogya.ac.id
}

\begin{abstract}
Abstrak
Tujuan penelitian ini ingin mengetahui efektivitas pelatihan customer service orientation untuk menurunkan emotional exhaustion karyawan pemasaran. Penelitian ini menggunakan teknik purposive sampling, pada karyawan pemasaran PT. Toyota Hadji Kalla Makassar yang berjumlah 30 orang kelompok eksperimen dan 30 orang sebagai kelompok kontrol. Penelitian ini menggunakan rancangan penelitian The Untreated Control Group Design Dependent Pretest and Posttest Samples. Pengumpulan data menggunakan skala sikap model Likert yaitu Skala Emotional Exhaustion. Hipotesis penelitian diuji menggunakan Anova mixed design. Hasil penelitian menunjukkan nilai $\mathrm{F}=195.662(\mathrm{p}<0,005)$ artinya perubahan skor pretest menuju postest pada kedua kelompok (eksperimen-kontrol) berbeda secara signifikan. Selanjutnya, perbedaan rerata pada kelompok eksperimen signifikan $(M D=39,633$; atau $\mathrm{p}<0,05)$. Sedangkan pada kelompok kontrol tidak signifikan $(\mathrm{MD}=2,600 ; \mathrm{p}=0,170$ atau $\mathrm{p}>0,05)$. Kesimpulannya, Pelatihan Customer Service Orientation efektif untuk menurunkan emotional exhaustion karyawan pemasaran.
\end{abstract}

Kata Kunci: Emotional exhaustion, customer service orientation, pelatihan.

\begin{abstract}
The purpose of this study was to determine the effectiveness of customer service orientation training to reduce the emotional exhaustion of marketing employees. This research uses the purposive sampling technique. The research subjects were marketing employees of PT. Toyota Hadji Kalla Makassar. Thirty employees as the experimental group and another thirty employees as the control group. This study uses The Untreated Control Group Design Dependent Pretest and Posttest Samples research design. Data collection used the Likert model attitude scale that is the Emotional Exhaustion Scale. The research hypothesis was tested using Anova mixed design. The results showed a value of $F=195,662(p<0.005)$ which means that the change in the pretest to posttest scores in the two groups (experiment-control) was significantly different. Furthermore, the mean difference in the experimental group was significant $(M D=39.633$; or $p<0.05)$. Whereas the control group was not significant $(M D=2,600 ; p=0.170$ or $p>0.05)$. In conclusion, Customer Service Orientation Training is effective in reducing the emotional exhaustion of marketing employees.
\end{abstract}

Kata Kunci: Emotional exhaustion, customer service orientation, pelatihan.

\section{PENDAHULUAN}

Karyawan perusahaan yang bertugas melakukan penjualan, pendistribusian, dan promosi langsung kepada konsumen dikenal dengan sebutan karyawan pemasaran (Setiawan, 2015). Kotler (2003) menyatakan bahwa tenaga pemasaran memiliki peran ganda, baik sebagai penghubung perusahaan kepada konsumen maupun sebagai pembawa informasi yang berguna bagi peru sahaan tentang konsumen. Peran ganda tersebut mengarahkan profesi ini menghadapi tuntutan dalam bekerja yang tidak terlepas dari adanya pelibatan emosi yang lebih intens (Kusriyani, Magdalena, dan Paramita, 2016). 
Kotler (2003) menyatakan bahwa tenaga pemasaran memiliki peran ganda, baik sebagai penghubung perusahaan kepada konsumen, maupun sebagai pembawa informasi yang berguna bagi perusahaan tentang konsumen. Peran tersebut menjadikan profesi ini menghadapi tuntutan dalam bekerja yang relatif berat dengan pelibatan emosi yang tinggi. Menurut Ratnaningsih (2007), terdapat sejumlah tuntutan yang harus dipenuhi karyawan pemasaran seperti berpenampilan menarik, berperilaku ramah, mampu mengatur emosi dan menunjukkan emosi positif pada konsumen. Hasil penelitian Houkes, Janssen, Jonge, dan Bakker (2003) mengungkapkan bahwa tuntutan dan pelibatan emosi yang tinggi akan berdampak pada kecenderungan karyawan untuk mengalami kelelahan emosi (emotional exhaustion).

Kelelahan emosi merupakan keadaan dimana karyawan kehabisan tenaga dalam menggambarkan perasaan emosionalnya sebagai akibat dari tingginya tuntutan pekerjaan yang dihadapi. Ada 2 aspek emotional exhaustion yang terdiri atas kelelahan fisik dan kelelahan mental (psikis). Kelelahan fisik yang terjadi pada individu dalam bentuk sakit kepala, merasa kaku di bagian bahu, pundak, leher dan nyeri di bagian punggung. Kelelahan mental atau psikologis muncul dalam bentuk seperti ketegangan, kurang mampu berkonsentrasi, berkurangnya tingkat kewaspadaan, berkurangnya gairah untuk bekerja, mudah lupa, mudah bersedih, merasa tidak berdaya, mudah marah, dan tidak percaya diri.

Perusahaan yang mengalami kondisi yang mengharuskan karyawan melibatkan emosi lebih intens selama bekerja salah satunya adalah PT Toyota Hadji Kalla Makassar. Perusahaan ini merupakan perusahaan yang bergerak di bidang otomotif sebagai penyedia solusi transportasi di Sulawesi Selatan bahkan di Kawasan Timur Indonesia. Misi dari perusahaan ini adalah menyediakan kendaraan Toyota kepada masyarakat dengan memberikan kualitas pelayanan terbaik. Salah satu penilaian mengenai kualitas pelayanan dari Toyota adalah kualitas kerja karyawan pemasaran sebagai ujung tombak sebuah perusahaan yang bergerak dalam bidang penjualan otomotif. Karyawan dihadapkan pada tuntutan tugas yang berat dan penyediaan layan an yang prima. Kondisi ini menjadi salah satu yang dapat memicu seorang karyawan pemasaran mengalami emotional exhaustion.

Kelelahan emosional (emotional exhaustion) timbul karena seseorang bekerja terlalu intens, berdedikasi dan komitmen, beban bekerja padat dan terlalu lama, serta memandang kebutuhan dan keinginan pribadinya sebagai hal kedua. Emotional exhaustion dapat menimbulkan dampak yang cukup mendalam, baik bagi karyawan maupun organisasi, seperti penurunan kinerja karyawan, kualitas service recovery performance, penurunan job satisfaction dan komitmen organisasi, dan meningkatnya jumlah turnover (Won-Moo, Moon, \& Su-Jin, H. 2015; Choi, Kim, Lee, \& Lee, 2014). 
Karyawan pemasaran PT Toyota Hadji Kalla Makassar memiliki uraian tugas di antaranya setiap karyawan diberikan target minimal 1-2 mobil yang berhasil dijual untuk waktu 1 bulan yang telah ditentukan oleh perusahaan. Hal tersebut dijadikan spirit setiap karyawan dalam meningkatkan intensitas kerjanya. Selain itu, sebagai bentuk komitmen karyawan pemasaran terhadap PT Toyota Hadji Kalla Makassar, para karyawan juga dituntut untuk mampu menjalin interaksi yang harmonis dengan para konsumen, meskipun kondisi karyawan kurang sehat atau kurang kondusif (hasil wawancara dengan Direktur HRD 23 April 2019). Selanjutnya, dalam proses kerja karyawan pemasaran seringkali dihadapkan pada berbagai komplain dari pelanggan. Komplain pelanggan sebenarnya bukanlah pekerjaan utamanya karena menjadi tanggung jawab bagian pelayanan konsumen (customer service) tetapi kenyataannya ketika pelanggan komplain terhadap produk PT Toyota Hadji Kalla Makassar, maka karyawan pemasaran turut dilibatkan di dalam penyelesaian permasalahan yang terjadi.

Karyawan di PT Toyota Hadji Kalla diberikan target pemasaran produk mobil Toyota pada waktu yang telah ditentukan oleh pihak perusahaan. Selain itu, karyawan juga diberikan tugas untuk memberikan penjelasan setiap ada komplain dari para konsumen terkait produk yang telah dibeli. Hasil studi awal menggunakan angket pada tanggal 4 s.d 5 Januari 2019 terhadap 74 orang karyawan pemasaran di PT Toyota Hadji Kalla diketahui bahwa terdapat 60 karyawan yang menyatakan keluhan yang dirasakan meliputi sulit berkonsentrasi, mudah lupa, seringkali merasa lelah, sakit kepala, merasa tidak berdaya, mudah merasa tertekan dan tegang, serta mudah marah. Keluhan tersebut terutama dirasakan ketika menghadapi adanya tuntutan dari perusahaan dan komplin dari para konsumen. Keluhan konsumen yang sering diterima oleh karyawan misalnya; pembatalan unit yang sebelumnya telah dipesan, lamanya masa tunggu konsumen terhadap unit yang telah ditransaksikan, durasi penyelesaian surat-surat kelengkapan unit yang terlalu panjang, serta inkonsistensi terhadap kesepakatan antara pihak perusahaan (karyawan pemasaran) dengan konsumen terkait model pembayaran uang muka (down payment) dan pengembalian uang muka (cash back). Berdasarkan banyaknya jumlah dan jenis keluhan yang diterima, sebanyak $81 \%$ karyawan mengaku merasa kelelahan saat harus menghadapi konsumen dengan keluhan-keluhan tersebut. Keluhan karyawan menunjukkan adanya tekanan psikologis baik berupa stres kerja, lebih mudah lupa, mudah bersedih hingga menangis, merasa tidak berdaya, sering cepat marah, merasa cemas, merasa malas masuk kerja, tidak percaya diri, dan berkeluh kesah maupun keluhan fisik seperti mudah lelah, sakit kepala, dan tegang. Kondisi tersebut mengindikasikan bahwa karyawan mengalami emotional exhaustion seperti yang dikemukakan oleh Cropanzano dan Wright (1998). Hasil studi awal juga mengungkapkan bahwa terdapat 51 karyawan yang mengalami emotional exhaustion pada kategori sedang, dan 9 orang karyawan berada pada kategori tinggi, serta 14 orang karyawan berada pada kategori rendah.

Salah satu strategi yang dapat digunakan untuk menurunkan emotional exhaustion karyawan pemasaran adalah melalui pelatihan Customer service orientation (CSO). Erena, Ayasc, dan 
Hacioglu (2013) mengemukakan bahwa pelatihan dapat memberikan efek yang berarti dalam menurunkan kelelahan emosi yang dihadapi karyawan. Hasil penelitian Hadjam (2001) juga menunjukkan bahwa pemahaman terhadap pelayanan prima dapat melalui pelatihan dan umpan balik. Pelatihan CSO merupakan faktor yang berpengaruh dan dapat mengurangi emotional exhaustion pada karyawan akibat perilaku konsumen yang tidak menyenangkan. Karyawan akan merasakan emotional exhaustion ketika terdapat keluhan dan perilaku agresi verbal yang dilakukan konsumen dari waktu ke waktu. Karena itu, diperlukan customer service orientation sebagai upaya untuk mengurangi emotional exhaustion karyawan (Yoo, Kim, \& Lee, 2015).

Pelatihan customer service orientation dalam penelitian ini menggunakan modul pelatihan yang melibatkan dimensi customer service yang dikembangkan oleh Brown, Donavan, Licata, dan Mowen (2002) meliputi dimensi kebutuhan dan dimensi kesenangan. Sikula (2000) mendefinisikan pelatihan sebagai sesuatu proses pendidikan jangka pendek dengan menggunakan prosedur yang sistematis dan terorganisir, sehingga karyawan operasional belajar pengetahuan teknik pengerjaan dan keahlian untuk tujuan tertentu. Adapun definisi customer service orientation adalah keinginan individu untuk mengekspresikan emosi positif kepada konsumen yang cenderung akan menjadi perilaku kerja karena pada dasarnya beberapa karyawan merasa senang melakukan perilaku tersebut (Allen, Pugh, Grandey, \& Groth, 2010). Brown, Mowen, Donavan, dan Licata (2002) mengemukakan bahwa customer service orientation merupakan kecenderungan karyawan untuk berinteraksi dengan konsumen. Karyawan yang memiliki customer service orientation tinggi memiliki dua kemampuan yang dirasakan dan dapat menjadi motivasi bagi karyawan, yakni keyakinan karyawan terhadap kemampuan diri untuk memuaskan konsumen, dan motivasi dalam diri karyawan untuk memuaskan konsumen.

Brown, dkk. (2002) mengemukakan ada 2 dimensi CSO yaitu: 1) Dimensi kebutuhan, berkaitan dengan kepercayaan diri karyawan dalam memenuhi kebutuhan dan keinginan konsumen, seperti membantu dalam mencapai tujuan dan memberikan pelayanan yang memuaskan kepada konsumen, dan 2) Dimensi kesenangan, dimana karyawan menikmati interaksi dan melayani konsumen dengan baik, seperti mudah tersenyum dan memiliki rasa empati terhadap konsumen.

Banyak artikel yang membahas mengenai mengenai emotional exhaustion (Yoo, Kim \& Lee, 2015; Won-Moo, Moon, \& Su-Jin, 2015; Kim, dkk., 2012; \& Shu, Wei, \& Peng, 2019). Hal tersebut di antaranya Yoo, Kim \& Lee (2015) mengukur peran costumer orientation terhadap emotional exhaustion dan service recovery performance pada karyawan restoran di Korea Selatan. Lebih lanjut, Won-Moo, Moon, \& Su-Jin, (2015) mengukur customer incivility (ketidaksopanan pelanggan) terhadap emotional labor karyawan (surface acting) dan bagaimana surface acting meningkatan emotional exhaustion dalam bekerja. Sedangkan, Kim, dkk. (2012) meneliti pengaruh customer-related social stressor terhadap emotional 
exhaustion. Kebaruan pada artikel ini terletak pada metode penelitian yang digunakan. Penelitian sebelumnya bersifat korelasional. Sedangkan penelitian ini menggunakan metode eksperimen kuasi dengan memberikan treatment berupa pelatihan. metode penelitian yang digunakan. Penelitian sebelumnya bersifat korelasional. Sedangkan penelitian ini menggunakan metode eksperimen kuasi dengan memberikan treatment berupa pelatihan.

Berdasarkan uraian di atas, maka peneliti melakukan pelatihan customer service orientation sebagai salah satu alternatif intervensi yang dapat dilakukan untuk menurunkan emotional exhaustion pada karyawan pemasaran. Rumusan masalah dalam penelitian ini adalah apakah pelatihan customer service orientation (CSO) efektif untuk menurunkan emotional exhaustion karyawan pemasaran PT Toyota Hadji Kalla Makassar?

\section{METODE}

Subjek yang dijadikan Kelompok Eksperimen adalah karyawan dari PT Toyota Hadji Kalla Makassar, sedangkan subjek di Kelompok Kontrol adalah karyawan dari PT Toyota Hadji Kalla cabang Gowa. Karakteristik subjek sebagai karyawan aktif, kondisi emotional exhaustion berada pada kategori sedang dan tinggi, dan direkomendasikan oleh Manajer perusahaan, serta bersedia mengikuti seluruh proses penelitian. Subjek penelitian diambil dengan menggunakan teknik purposive sampling sebanyak 60 orang karyawan, masing-masing 30 orang sebagai subjek kelompok eksperimen dan 30 sebagai kelompok kontrol.

Penelitian ini menggunakan rancangan penelitian The Untreated Control Group Design Dependent Pretest and Posttest Samples (Shadish, Cook, \& Campbell, 2002), dimana pada model ini terdapat dua kelompok yakni kelompok kontrol (KK) dan kelompok eksperimen (KE). Kedua kelompok dilakukan pengukuran sebanyak dua kali yakni pretest dan posttest.

Metode pengumpulan data yang digunakan adalah skala sikap model Likert yang telah divalidasi dan di ujicobakan. Skala yang akan digunakan adalah Skala Emotional Exhoustion. Adapun teknik analisis data menggunakan Anova Mixed Design (Field, 2005). Emotional exhaustion dalam penelitian ini adalah kelelahan fisik dan kelelahan psikologis yang dialami karyawan pemasaran PT Toyota Hadji Kalla Makassar, mengacu pada ciri yang dikembangkan oleh Cropanzano dan Wright (1998). Kelelahan fisik dalam penelitian ini meliputi sakit kepala, merasa kaku di bagian bahu, pundak, leher dan nyeri di bagian punggung. Sedangkan, kelelahan psikologis meliputi ketegangan, kurang mampu berkonsentrasi, berkurangnya tingkat kewaspadaan, berkurangnya gairah untuk bekerja, mudah lupa, mudah bersedih, merasa tidak berdaya, mudah marah, dan tidak percaya diri pada karyawan pemasaran.

Berdasarkan hasil uji coba skala yang dilakukan terhadap 42 orang karyawan pemasaran PT Toyota Hadji Kalla cabang Maros, diketahui skor item total correlation yang bergerak 0,075 s.d. 
0,891 . Hal ini menunjukkan bahwa terdapat item dalam tes pengetahuan tersebut yang tidak memiliki kesesuaian fungsi dengan fungsi skala dalam mengungkapkan perbedaan individual (Azwar, 2012). Dengan demikian, hasil validitas terhadap 40 item skala menunjukkan 35 item valid, dan 5 item tidak valid. Reliabilitas untuk Skala Emotional Exhaustion menunjukkan nilai Cronbach's Alpha yang menghasilkan koefisien sebesar 0,946, sehingga skala tersebut menunjukkan kategoribaik.

Peneliti menggunakan modul pelatihan yang dikembangkan berdasarkan dimensi customer service yang mengacu pada teori Donavan, Licata, dan Mowen (2002) meliputi dimensi kebutu han dan dimensi kesenangan. Pelatihan CSO diberikan kepada kelompok eksperimen (KE) yang dilaksanakan selama 1 kali pertemuan selama \pm 6 jam (26 April 2019).

Validasi isi modul CSO melibatkan penilai ahli (professional judgment) yaitu Dr. Resekiani Mas Bakar, S.Psi., M.Psi., Psikolog. Alasan memilih penilai ahli yaitu memiliki pengetahuan mengenai customer service orientation training dan emotional exhaustion, memiliki pengetahuan dan keterampilan menyusun dan memvalidasi modul pelatihan, serta memiliki pengetahuan ataupun pengalaman bekerja minimal 2 tahun pada bidang perusahaan industri (Meyer dan Booker, 2001).

Berdasarkan hasil validasi diketahui bahwa ice breaking yang diberikan disesuaikan dengan tema pelatihan, dan yang dapat lebih menarik atensi peserta. Selanjutnya, materi yang dipaparkan lebih diperjelas isinya, dan lebih mempertegas target capaian setiap sesi penyajian materi. Selain itu, validator juga memvalidasi tugas yang diberikan kepada subjek dengan menyarankan pengubahan bentuk tugas soal pengetahuan yang awalnya berbentuk pertanyaan essai menjadi pertanyaan berupa pilihan soal benar-salah agar dapat memudahkan proses penilaian. Revisi modul CSO sesuai saran validator dilakukan sampai modul dianggap layak untuk digunakan.

Setelah modul CSO divalidasi, selanjutnya dilakukan ujicoba modul. Ujicoba modul dilakukan pada tanggal 13 s.d. 15 April 2019 dengan peserta 20 orang yang memiliki kriteria yang sama dengan kriteria subjek penelitian yakni karyawan pemasaran PT Toyota Hadji Kalla cabang Maros yang bersedia menjadi subjek untuk ujicoba modul CSO ini. Ujicoba modul dilakukan dengan menggunakan fasilitator yang berlatar belakang psikolog yang memiliki pengetahuan mengenai CSO dan emotional exhaustion, serta memiliki pengalaman menjadi trainer di perusahaan dan industri. Evaluasi dari peserta ujicoba diberikan dalam bentuk meminta rating yang bergerak dari skala 1 (tidak sesuai) hingga 5 (sesuai). Penilaian diberikan untuk fasilitator, materi, dan lain-lain. Berdasarkan hasil evaluasi, peserta dinilai dapat memahami esensi materi yang terdapat di dalam modul, pemberian ice breaking lebih diperbanyak, waktu pelaksanaan pelatihan dipertimbangkan agar lebih kondusif. 
HASIL DAN PEMBAHASAN

Tabel 1. Hasil Uji Efek Dalam-Subjek

\begin{tabular}{lllllll}
\hline Variabel & & $\begin{array}{l}\text { Jumlah } \\
\text { Kuadrat }\end{array}$ & Db & Rerata Kuadrat & F & p \\
\hline $\begin{array}{l}\text { Waktu } \\
\text { Greenhouse-Geisser }\end{array}$ & $*$ & 10286,008 & 1 & 10286,008 & 195,662 & 0.00 \\
\hline
\end{tabular}

Keterangan:* berarti interaksi antara waktu dan kelompok

Berdasarkan hasil uji efek dalam subjek (Tests of Within-Subjects Effects) pada tabel 1 diketahui bahwa pada baris time*group dan sub baris Greenhouse-Geisser. Hasilnya adalah F= 195.662 dengan signifikansi $0,001(\mathrm{p}<0,005)$ artinya terdapat interaksi antara waktu (pretestposttets) dan kelompok (Kelompok Eksperimen-Kelompok Kontrol). Interaksi menunjukkan bahwa perubahan skor pretest menuju postest pada kedua kelompok (eksperimen-kontrol) adalah berbeda secara signifikan.

Tabel 2. Perbandingan Waktu

\begin{tabular}{|c|c|c|c|c|c|c|c|}
\hline \multirow{2}{*}{ Kelompok } & \multirow{2}{*}{$\begin{array}{l}\text { Rerata } \\
\text { Pre Test }\end{array}$} & \multirow{2}{*}{$\begin{array}{l}\text { Rerata } \\
\text { Post Test }\end{array}$} & \multirow{2}{*}{$\begin{array}{l}\text { Selisih } \\
\text { Rerata }\end{array}$} & \multirow{2}{*}{$\begin{array}{l}\text { Standar } \\
\text { Eror }\end{array}$} & \multirow{2}{*}{$\mathrm{p}$} & \multicolumn{2}{|c|}{$\begin{array}{l}\text { Interval } \\
\text { Kepercayaan dari } \\
\text { perbedaan } 95 \%\end{array}$} \\
\hline & & & & & & $\begin{array}{l}\text { Batas } \\
\text { Bawah }\end{array}$ & $\begin{array}{l}\text { Batas } \\
\text { Atas }\end{array}$ \\
\hline $\mathrm{KE}$ & 97,634 & 58,033 & $39633^{*}$ & 1,872 & 0,00 & 35,886 & 43,381 \\
\hline KK & 93,533 & 90,933 & 2,600 & 1,872 & 0,17 & $-1,147$ & 6,347 \\
\hline
\end{tabular}

Perubahan emotional exhaustion pada kelompok eksperimen adalah signifikan (perbedaan rerata $=39,633$, dengan nilai signifikansi $0,001(\mathrm{p}<0,05)$. Sedangkan pada kelompok kontrol adalah tidak signifikan (selisih rerata $=2,600$; dengan nilai signifikansi 0,170 atau $\mathrm{p}>0,05$ yang berarti tidak signifikan). Hal ini menunjukkan bahwa Pelatihan Customer Service Orientation yang diberikan kepada kelompok eksperimen cukup efektif dalam menurunkan emotional exhaustion. Pada kelompok kontrol juga terjadi penurunan yang terlihat dari nilai perbedaan rerata sebesar 2,600, tetapi penurunan tersebut tidak signifikan yang ditunjukkan dengan nilai signifikansi 0,17 atau $\mathrm{p}>0,05$.

Berdasarkan hasil kategorisasi diperoleh data sebagai berikut :

Tabel 3. Kategorisasi Pre-Posttest KE dan KK

\begin{tabular}{llll}
\hline Kelompok & Kategorisasi & $\begin{array}{l}\text { Pre Test } \\
\text { (jumlah orang) }\end{array}$ & $\begin{array}{l}\text { Post test } \\
\text { (jumlah orang) }\end{array}$ \\
\hline KE & Tinggi & 6 & 0 \\
& Sedang & 24 & 0 \\
KK & Rendah & 0 & 30 \\
& Tinggi & 3 & 3 \\
& Sedang & 27 & 21 \\
& Rendah & 0 & 6 \\
\hline
\end{tabular}


Berdasarkan tabel 3 di atas diketahui bahwa terdapat perbedaan kategori emotional exhaustion pada Kelompok Eksperimen (KE) sebelum (pretest) dan setelah (posttest) diberikan pelatihan CSO yakni terjadi penurunan emotional exhaustion pada KE dimana tidak ada lagi subjek yang berada pada kategori emotional exhaustion yang tinggi dan sedang, akan tetapi 30 orang subjek menunjukkan emotional exhaustion menurun ke kategori rendah. Sedangkan, pada kelompok Kontrol, terdapat perbedaan kategori emotional exhaustion sebelum (pretest) dan setelah (posttest) tes diberikan, tetapi hanya 6 orang yang mengalami penurunan ke kategori sedang, dan 6 orang berada pada kategori rendah. Oleh karena itu, dapat disimpulkan bahwa kondisi emotional exhaustion pada KE setelah mendapat pelatihan CSO mengalami penurunan yang lebih berarti dibandingkan KK yang tidak diberikan pelatihan CSO.

Tabel 4. Hasil Uji Multivarian

\begin{tabular}{lllllllll}
\hline Kelompok & Nilai & $\mathrm{F}$ & \multicolumn{3}{c}{ Hipotesis df Error df } & $\mathrm{p}$ & $\begin{array}{l}\text { Partial Eta } \\
\text { Squared }\end{array}$ \\
\hline KE & Wilks' lambda & 0,115 & $4,482 \mathrm{E} 2^{\mathrm{a}}$ & 1,000 & 58,000 & 0,000 & 0,885 \\
KK & Wilks' lambda & 0,968 & $1,929^{\mathrm{a}}$ & 1,000 & 58,000 & 0,170 & 0,032 \\
\hline
\end{tabular}

Pada kelompok eksperimen tertulis Partial Eta Squared sebesar 0,885 artinya Pelatihan Customer Service Orientation (CSO) yang diberikan efektif menurunkan emotional exhaustion sebesar $88,5 \%$, sedangkan penurunan kelompok kontrol sebesar 0,032 atau $3,2 \%$

Perubahan pengetahuan mengenai CSO melalui pelatihan CSO kemudian memberikan dampak pada penurunan skor emotional exhaustion pada kelompok eksperimen. Hal ini ditunjukkan dari hasil Tests of Within-Subjects Effects yang menunjukkan bahwa perubahan skor pretest menuju postest pada kedua kelompok (eksperimen-kontrol) adalah berbeda secara signifikan. Selanjutnya, perubahan emotional exhaustion pada kelompok eksperimen adalah signifikan, tetapi pada kelompok kontrol tidak signifikan. Hal ini menunjukkan bahwa Pelatihan CSO yang diberikan kepada kelompok eksperimen efektif dalam menurunkan emotional exhaustion.

Hasil penelitian ini sesuai dengan pendapat Johnson dan Johnson (2000) bahwa pelatihan merupakan salah satu metode yang dianggap efektif untuk meningkatkan dan mengubah struktur kognitif, meningkatkan motivasi, memodifikasi perilaku dan sikap, serta meningkatkan keterampilan. Dengan meningkatnya pengetahuan CSO subjek KE serta adanya reaksi positif terhadap pelatihan CSO tersebut ternyata memberikan dampak penurunan emotional exhaustion yang juga ditunjukkan berdasarkan kategorisasi emotional exhaustion di KE dan KK. Pada KE setelah diberikan pelatihan CSO, tidak terdapat subjek yang berada pada kategori emotional exhaustion yang tinggi dan sedang, Sedangkan, pada kelompok kontrol hanya 6 orang yang mengalami penurunan ke kategori sedang, dan 6 orang berada di kategori rendah.

Karyawan dengan kecenderungan customer service orientation sales dalam kategori tinggi lebih mudah memahami keadaan dan menikmati proses pemecahan masalah yang dilakukan serta 
menangani stress sosial yang dapat mengurangi efek karyawan merasakan emotional exhaustion. Individu dengan tingkat customer service orientation rendah memiliki tingkat kepercayaan diri yang rendah terhadap stress sosial yang terkait dengan konsumen sehingga karyawan tidak mampu dalam menyelesaikan masalah tersebut. Hal ini dapat memicu terjadinya kelelahan emosi pada karyawan (Hur, Moon, \& Han, 2014; Kim, dkk., 2012).

Harris, Artis, Walters, dan Licata (2006) menyatakan bahwa emotional exhaustion terjadi pada individu yang mengalami kehilangan sumber daya akibat tuntutan psikologis yang sangat menekan selama bekerja. Kondisi emosi yang sangat tertekan akan berdampak buruk baik pada pribadi maupun pada kualitas pekerjaan yang dijalankan. Akibatnya, performansi kerja tidak sesuai dengan target perusahaan. Pelatihan CSO telah membentuk karyawan pemasaran menjadi sosok yang tangguh, berorientasi pelayanan dan tanggap dengan keluhan pelanggan. Dalam memberikan pelayanan harus mengedepankan terpenuhinya kebutuhan dan keinginan pelanggan, sehingga bisa memberikan kesenangan bagi pelanggan dalam berinteraksi. Oleh karena itu, karyawan dengan customer service orientation yang lebih tinggi akan menilai bahwa penyebab emotional exhaustion lebih bersifat eksternal, bersifat sementara, dapat dikendalikan, dan dapat diatasi dengan cepat sehingga tidak mempengaruhi kualitas kinerjanya.

\section{KESIMPULAN}

Pelatihan customer service orientation efektif untuk menurunkan emotional exhaustion karyawan pemasaran PT Toyota Hadji Kalla Makassar dengan efektivitas sebesar sebesar 88,5\%. Hal tersebut ditunjukkan dari hasil Tests of Within-Subjects Effects bahwa terdapat interaksi antara waktu (pretest-posttets) dan kelompok (Kelompok Eksperimen-Kelompok Kontrol). Interaksi menunjukkan bahwa perubahan skor pretest menuju postest pada kedua kelompok (eksperimen kontrol) adalah berbeda secara signifikan. Selain itu, berdasarkan hasil evaluasi pelatihan CSO diketahui bahwa hasil skor pretest dan posttest soal pengetahuan CSO Training mengalami peningkatan pada KE. Selanjutnya, berdasarkan hasil evaluasi level reaksi diketahui bahwa rerata skor evaluasi materi menunjukkan adanya reaksi yang positif pada subjek tentang materi, fasilitator, dan aspek lainnya yang mendukung proses CSO training berjalan kondusif dengan hasil optimal.

\section{DAFTAR PUSTAKA}

Allen, J. A., Pugh, D., Grandey, A. A. \& Groth, M. (2010). Following display rules in good or bad faith?: Customer orientation as a moderat or of the display rule-emotional labor relation ship. Human Performance, 23, 1-15. DOI: 10.1080/08959281003621695.

Brown, T. J., Mowen, J. C., Donavan, D. T., \& Licata, J. W. (2002). The customer orientation of service workers: Personality trait effects on self and manajer performance ratings. Journal of Marketing Research, 39, 110-119. 
Choi, C. H., Kim, T., Lee, G., \& Lee, S. K. (2014). Testing the stressor-strain-outcome model of customer-related social stressors in predicting emotional exhaustion, customer orientation and service recovery performance. International Journal of Hospitality Management, 36, 272-285. http://dx.doi.org/10.1016/j.ijhm.2012.09.009

Cropanzano, R. \& Wright, T. A. (1998). Emotional exhaustion as a predictor of job performance and voluntary turnover. Journal of Applied Psychology, 83(3), 486-493.

Donavan, D. T., Brown, T. J., \& Mowen, J. C. (2004). Internal benefits of service-worker customer orientation: Job satisfaction, commitment, and organizational citizenship behaviors. Journal of Marketing, 68, 128-146.

Erena, S.S., Ayasc, N., \& Hacioglu, G. (2013). The effect of service orientation on financial performance: The mediating role of job satisfaction and customer satisfaction. Procedia Social and Behavioral Sciences 99, 665-672. (Online). (https://core.ac.uk/download/pdf/82165525.pdf). (Diakses, 4 Januari 2019).

Field, A. (2005). Discovering statistics using SPSS. London : Sage Publications.

Hadjam, N.R. (2001). Efektivitas pelayanan prima sebagai upaya meningkatkan pelayanan di rumah sakit (Perspektif Psikologi). Jurnal Psikologi, (2), 105 - 115. (Online). (https://media.neliti.com). (Diakses, 4 Januari 2019).

Harris, E. G., Artis, A. B., Walters, J. H., \& Licata, J. W. (2006). Role stressors, service worker job resourcefulness, and job outcomes: An empirical analysis. Journal of Business Research, 59. 407-415.

Hur, W. M., Moon, T. W., \& Han, S. J. (2014). The effect of customer incivility on service employees' customer orientation through double-mediation of surface acting and emotional exhaustion. Journal of Service Theory and Practice, 25(4), 394-413.

Johnson, D., W \& Johnson, F. P. (2000). Joining together group theory and group skills. Boston: Allyn \& Bacon.

Kim, T. T., Paek, S., Choi, C. H., \& Lee, G. (2012). Frontline service employees' customer-related social stressors, emotional exhaustion, and service recovery performance: Customer orientation as a moderator. Journal of Serv Bus, 6, 503-526

Kusriyani, T., Magdalena, M., \& Paramita, P. D. (2016). Pengaruh konflik peran, kelelahan emosional, dan kepuasan kerja terhadap intensitas turnover yang dimediasi komitmen organisasi pada dinas pasar Kota Semarang. Journal of Management, 2(2), 1-13.

Kotler, P. (2003). Manajemen pemasaran (edisi kesebelas). Jakarta: Indeks kelompok Gramedia.

Setiawan, D. P (2015). Kajian kritis mengenai definisi dan ruang lingkup salesmanship. Jurnal Ilmiah Manajemen dan Bisnis 1, (1), (Online). (https://media.neliti.com/media/publication). (Diakses, 3 Januari 2019).

Shadish,W. R., Cook,T. D., \& Campbell, D. T (2002). Experimental and quasi experimental design for generalized causal inference. USA: Houghton Mifflin Company.

Sikula, A. E (2000). Manajemen sumber daya manusia. Erlangga: Bandung.

Storbacka, K., \& Lehtinen J.R. (2001). Customer relationship management: Creating competitive advantage through win win solution strategies. Singapore: McGraw Hill Book co.

Won-Moo H., Moon, T. W., Su-Jin, H. (2015). The effect of customer incivility on serviceemployees' customer orientation through double-mediation of surface acting and emotional. Journal of Service Theory and Practice, 25(4), 394 - 413. http://doi.org/10.1108/JSTP-02-2014-0034.

Yoo, J. J-E., Kim, T. T., \& Lee, G. (2015). When customers complain: The value of customer orientation in service recovery. Cornell Hospitality Quarterly, 56(4), 411-426. (Online). (https://www.researchgate.net/publication). (Diakses, 3 Janu ari 2019). 